Огляди

DOI: $10.31793 / 1680-1466.2021 .26-3.298$

\title{
Експериментальне моделювання метаболічного синдрому, індукованого дієтою, у лабораторних тварин
}

\section{H.І. Левчук, О.С. Лукашеня, О.І. Ковзун}

ДУ «Інститут ендокринології та обміну речовин ім. В.П. Комісаренка НАМН України»

\begin{abstract}
Резюме. Розуміння причин виникнення, діагностики, профілактики та лікування метаболічного синдрому (МС) залишається пріоритетним напрямком сучасної ендокринології. Це симптомокомплекс, який характеризується основними клінічними проявами - збільшенням маси тіла, порушенням толерантності до глюкози, дисліпідемією, артеріальною гіпертензією та інсулінорезистентністю (IP). Наразі він є одним із найскладніших і найнебезпечніших захворювань, що передує виникненню цукрового діабету 2-го типу і розвитку серцево-судинних ускладнень, які є основними причинами смертності населення. Враховуючи стрімке зростання захворюваності впродовж останніх років у всіх країнах світу, виникає потреба в проведенні експериментів на тваринах із метою здобуття нових знань про механізми розвитку патологічного процесу та окремих їі проявів, використання лікарських сполук для їх безпечного застосування та корекції цього стану. Для експериментального моделювання МС найчастіше надають перевагу дослідам на щурах або мишах. Цей огляд літератури присвячено порівняльному аналізу та короткому опису експериментального моделювання МС, індукованого дієтою, у гризунів. Розглянуто основні типи дієт (високожирова (ВЖД), високовуглеводна та висококалорійна комбінована (ВККД)) і висвітлено відмінності прояву патологічного стану за різних умов харчування у тварин залежно від їх виду, лінії, статі, віку, умов і тривалості експерименту. Було показано, що ступінь вираженості розвитку біохімічних і патоморфологічних змін, характерних для метаболічних порушень, залежить від типу та відсоткового вмісту компонентів дієти. Відтворення умов моделювання і неоднорідність прояву МС у тварин створює певні труднощі при обґрунтуванні отриманих наукових результатів відповідно до поставленої мети дослідження. Саме ці обставини привертають підвищений науково-практичний інтерес зі сторони дослідників.
\end{abstract}

Ключові слова: метаболічний синдром, інсулінорезистентність, дієта.

MC належить до найпоширеніших захворювань серед населення всього світу. Це комплекс гормональних і метаболічних порушень, що є основою для розвитку цукрового діабету 2-го типу та супутніх захворювань, які спричиняють інвалідизацію та передчасну смерть (с) Н.І. Левчук, О.С. Лукашеня, О.І. Ковзун хворого. Основними клінічними проявами МС є збільшення маси тіла, порушення толерантності до глюкози, дисліпідемія, артеріальна гіпертензія та IP [1-3].

Враховуючи зростання показників розповсюдженості патологічного стану, актуальною проблемою сучасної ендокринології 
залишається розуміння причин його розвитку і прогресування, а також розробка та удосконалення методів діагностики, профілактики та лікування.

Для розв’язання вищезазначених задач виникає потреба вдаватися до проведення експериментальних досліджень на тваринах. Це дозволяє відтворити основні аспекти захворювання та здобути нові знання про механізми розвитку хвороби, а також оцінити вплив фармакологічних препаратів із метою їх застосування для корекції цієї патології. При цьому слід зауважити, що експериментальне моделювання хвороби на тваринах лише частково зображає патологію, яка характерна для людини. Така відмінність може полягати в індивідуальній особливості перебігу фізіологічних та біохімічних процесів в організмі людини й тварини.

На сьогодні не існує універсального методу моделювання МС в експериментальних тварин. У науковій літературі описано декілька способів його відтворення в лабораторних умовах. До найбільш поширених належать: ВЖД, високовуглеводна дієта, ВККд.

Враховуючи актуальність вищевикладеної проблематики, цей огляд літератури присвячено короткому опису та порівняльному аналізу основних підходів моделювання симптомокомплексу, індукованого дієтою.

Експериментальна модель МС, індукована жировою дієтою. Дієти, які у своєму складі містять високий вміст жирів, використовуються в основному для моделювання ожиріння. Його відсоток від загальної калорійності раціону, за даними різних дослідників, коливається в межах від 20 до 60\% [4-8]. Розвиток МС у гризунів залежить не лише від вмісту жиру в добовому раціоні, але й від його складу. Джерелом жирового компонента можуть слугувати жири рослинного (оливкова, кокосова і кукурудзяна олії) та тваринного походження (свинячий і яловичий жири) [7, 9, 10]. Найчастіше при моделюванні патологічного стану застосовують свиняче сало, яке складається з насичених i мононенасичених жирних кислот. З'ясовано, що такий хімічний склад індукує більш виражені прояви ожиріння та IP порівняно з дієтами, які багаті на інші типи жирних кислот. Надмірне надходження їх в організм спричиняе пошкодження $\beta$-клітин підшлункової залози (ПШЗ), зниження чутливості периферичних тканин до інсуліну, збільшення кількості абдомінально-вісцерального жиру, дисбаланс фосфоліпідного складу плазматичних мембран гепатоцитів, неалкогольну жирову хворобу печінки (стеатоз), дисліпідемію, підвищення рівня лептину та зниження рівня адипонектину в крові [5, 6, 9, 11-14].

$\mathrm{Y}$ роботі Buettner R. et al. було проведено порівняльний аналіз впливу ВЖД впродовж 12 тижнів, що містила у своєму складі різні жирові компоненти (свинячий і риб'ячий жири, оливкову та кокосову олії), на виникнення MC у самців щурів лінії Wistar [9]. Отримані результати засвідчили збільшення маси тіла, розвиток IP та зниження рівня адипонектину в плазмі крові тварин лише в групах, які утримувалися на дієті, що містила свинячий жир або оливкову олію. Стеатоз і підвищений вміст тригліцеридів у печінці було виявлено у всіх досліджуваних групах, крім щурів на дієті з риб'ячим жиром. Слід зазначити, що введення в раціон щурам ВЖД на основі риб'ячого жиру, не призводило до розвитку ознак МС.

Водночас необхідно зазначити, що сприйнятливість до ВЖД залежить від виду тварин. Так, показано, що щури ліній OsborneMendel, Sprague-Dawley, Wistar або миші ліній C57BL/6J i AKR мають схильність до розвитку ожиріння на цій дієті, тоді як щури лінії S5B/P1 і миші ліній A/J та SWR/J є більш стійкими [4, 15-17]. Для вивчення розвитку вікового ожиріння застосовують щурів лінії F344xBrown Norway [18].

Встановлено, що поява метаболічних порушень на тлі вживання ВЖД у щурів залежить від статі та лінії. Дослідження Poret J.M. et al. на самцях і самицях щурів різних ліній, які утримувалися на цій дієті, показали значну різницю в розвитку симптомів МС та рівнях експресії прозапальних цитокінів у вісцеральній і підшкірній жировій тканині [15]. Перебування на ВЖД, як у самців лінії Osborne-Mendel, так і лінії S5B/Pl призводить до підвищення рівня глюкози в крові, збільшення маси тіла та розвитку ожиріння. На відміну від самців, у самок щурів ВЖД призводила до збільшення маси тіла і розвитку ожиріння лише лінії Osborne-Mendel. Загалом самки щурів не відповідали критеріям розвитку МС. Рівень експресії цитокінів у вісцеральній і підшкірній жировій тканині в самців також був вищим 
порівняно зі самицями та різнився залежно від лінії. В іншій роботі продемонстровано відмінності ліпідного профілю в щурів ліній Wistar i Sprague Dawley, які перебували на ВЖД впродовж 4 тижнів [13]. Виявлено, що рівень ліпопротеїнів низької щільності підвищувався, а ліпопротеїнів високої щільності - знижувався. Проте зміни ліпідного профілю в щурів лінії Sprague Dawley були більш вираженими та супроводжувалися серцево-судинними ускладненнями.

Значну роль у розвитку ожиріння відіграє тривалість утримання на дієті, що становить, за даними різних дослідників, від 4 до 40 тижнів. Різниця термінів перебування піддослідних залежить від віку, виду та статі тварин [19].

За даними клінічних і фундаментальних досліджень, розвиток IP - ключового чинника МC - можливий за відсутності ожиріння. За даними Цапенко П.К. та ін. встановлено, що короткострокове (впродовж 2-4 тижнів) утримання щурів лінії Wistar на ВЖД, яка містила до 58\% свинячого жиру від загальної калорійності, супроводжувалося стійким зростанням показників глікемії без розвитку ожиріння. Автори висловили думку про те, що ця модель є більш придатною для вивчення механізмів розвитку IP без ожиріння та може використовуватися для дослідження відповідних механізмів розвитку МС [7].

Таким чином, розвиток основних ознак МС, індукованого шляхом застосування ВЖД, у гризунів залежить від складу та відсотку жиру, тривалості харчування і віку тварин.

Експериментальна модель МС, індукована вуглеводною дієтою. Для вивчення механізмів порушення обміну речовин, пов'язаних із $\mathrm{MC}$, широко використовується моделювання цього стану в тварин шляхом введення в їх раціон вуглеводів - фруктози або сахарози.

Фруктоза - це вуглевод, який належить до групи моносахаридів. Вона в основному всмоктується в системний кровотік за допомогою глюкозних транспортерів типу 2 і 5 та метаболізується в печінці з утворенням глюкози, лактату, тригліцеридів, вільних жирних кислот, сечової кислоти й метилгліоксаля. Фруктоза та її метаболіти прямо або опосередковано можуть викликати окислювальний стрес, хронічне запалення, ендотеліальну дисфункцію, підвищену кишкову проникність i, як наслідок, посилювати МС із порушенням функцій тканин і органів [20].

У низці робіт на моделях тварин продемонстровано, що надмірне споживання фруктози призводить до розвитку ознак, які відповідають стану IP: гіперглікемії, дисліпідемії, жирової інфільтрації печінки, функціональних порушень печінки (підвищення рівнів білірубіну, аланінамінотрансферази, аспартатамінотрансферази й лужної фосфатази) та нирок (зростання вмісту сечовини, сечової кислоти та креатиніну), активації процесів перекисного окиснення білків і ліпідів, зниження кількості інсулінових рецепторів, артеріальної гіпертензії та порушення мікробіоценозу кишківника [21-26].

Моделювання МС у щурів фруктозною дієтою можливе шляхом iï додавання до корму або до питної води. Відсоток вуглеводу в раціоні може коливатись від 10 до 66\% [25, 27-29].

У роботі Мархонь Н.О. та ін. на щурах-самцях було досліджено вплив фруктозної дієти, яка різнилася за відсотковим вмістом вуглеводного компонента, на показники МС [27]. Показано, що використання $10 \%$ розчину фруктози впродовж 8 тижнів сприяло помірному збільшенню маси тіла та незначному підвищенню рівня глюкози. Утримання щурів на дієті, яка містила $60 \%$ розчин фруктози мала певні переваги у виразності основних клінічних ознак МС, зокрема, розвитку гіперглікемії, гіпертригліцеридемії та гіперхолестеринемії. За іншими даними додавання фруктози до корму (60\%) або до питної води (10\%) щурам лінії Sprague-Dawley впродовж 8 тижнів викликало гіпертензію, гіперурикемію та гіпертригліцеридемію [28]. Проте ці параметри поступово посилювалися зі збільшенням тривалості споживання фруктози. Розвиток МС, індукований вуглеводом, було пов'язано із нирковими порушеннями, які характеризувалися гіпертрофією, артеріопатією, клубочковою гіпертензією і звуженням кортикальних судин. Перебування на дієті, збагаченої 60\% фруктозою, щурами цієї ж лінії мали більш виражені зміни, які характерні для МС, порівняно з тваринами, що отримували $10 \%$ питний розчин. Однак, вживання самцями щурів лінії Wistar розчину з низьким вмістом фруктози (7\%) впродовж 12 тижнів не призводило до змін базальних рівнів глюкози й інсуліну, порушення ліпідного обміну та розвитку стеатозу печінки [30]. Водночас виявлені 
морфологічні та біохімічні зміни, які пов’язані зі зменшенням загальної площі острівців ПШЗ, збільшенням кількості та маси $\beta$-клітин ПШЗ, порушенням толерантності до глюкози.

Морфологічні зміни внутрішніх органів у гризунів при розвитку МС, індукованого фруктозою, було також досліджено іншими науковцями. Встановлено, що 20\% розчин фруктози не впливав на масу нирок, але спричиняв гістоморфологічні зміни, зокрема, зменшення діаметрів ниркових корпускул і висхідної частини петлі Генле, ширини порожнини ниркових клубочків та збільшення діаметру проксимальних звивистих трубочок [29].

3'ясовано, що фруктозна дієта може порізному впливати на масу тіла в гризунів. В одних роботах показано, що цей вуглевод призводить до збільшення маси тіла, а в інших - не спостерігали вірогідних змін [26, 31-34]. Так, у дослідженнях Tillman E.J. et al. на мишах лінії C57BL/6, які перебували на висококалорійній фруктозній дієті (60\%) впродовж 14 тижнів, було продемонстровано відсутність приросту маси тіла [33]. Це було пов'язано з прискоренням метаболічних процесів, який визначали в нічний і денний періоди доби за рівнем спожитого $\mathrm{O}_{2}$ та виділеного $\mathrm{CO}_{2}$. Крім того, інші показники, які характерні для МС (рівні глюкози, тригліцеридів, лептину і вільних жирних кислот у крові цієї групи мишей) також залишалися без змін. Автори прийшли до висновку, що ця лінія мишей не чутлива до фруктозної дієти.

Також, відзначалися певні статеві відмінності застосування фруктозної дієти [35]. Перебування самців лінії Wistar на $10 \%$ розчині фруктози впродовж 8 тижнів викликало розвиток більш виразних ознак IP, ніж у самиць. Водночас лише в самців зафіксовано підвищення добової секреції сечової кислоти, що свідчить про iii гіперпродукцію.

Згідно з даними de Moura R.F. et al., метаболічна відповідь на фруктозну дієту в гризунів залежить від їхнього віку [36]. Встановлено, що утримання щурів лінії Wistar на 60\% фруктозі в сухому кормі є більш ефективним для розвитку основних ознак МС у дорослих (90 діб), ніж у молодих тварин (28 діб). При цьому тривалість перебування на дієті дорослих щурів становила 4 тижні, а молодих -8 тижнів. В обох групах щурів спостерігали порушення толерантності до глюкози, наявність IP і підвищення рівня тригліцеридів у крові, тоді як збільшення маси тіла та підвищення рівня загального холестерину, ліпопротеїнів низької та високої щільності і вмісту загальних ліпідів у печінці було зафіксовано лише в групі дорослих тварин.

Сахароза - органічна сполука, утворена залишками двох моносахаридів глюкози й фруктози. Цей дисахарид здатний викликати підвищення маси тіла, ожиріння, збільшення секреції інсуліну $\beta$-клітинами ПШЗ, порушення толерантності до глюкози, розвиток IP, дисліпідемію (підвищення рівнів тригліцеридів, ліпопротеїнів дуже низької щільності, загального холестерину), артеріальну гіпертензію, зростання маркерів функціонального стану печінки (аланінамінотрансферази та аспартатамінотрансферази) i зміну показників оксидативного стресу (малонового діальдегіду, супероксиддисмутази та глутатіону) в цій тканині [37-39].

На відміну від фруктози, сахароза спричиняє більш серйозні порушення структурних змін у печінці. Виявлено, що утримання на 40\% розчині сахарози двомісячних щурів лінії Wistar впродовж 180 діб призводило до зменшення числа гепатоцитів, високого ступеня вакуолізації та збільшення їх розмірів, появи колагену та помірного фіброзу [37]. У дослідженнях Corona-Pérez A. et al. показано, що 30\% розчин сахарози в щурів цієї ж лінії протягом 8 тижнів спричиняв подібний ефект щодо структурних змін печінки - розвитку стеатозу з ознаками помірного фіброзу [40].

Таким чином, вищезазначені вуглеводи є ефективними індукторами розвитку МС у гризунів. Ступінь порушень метаболічних процесів у тварин залежить від концентрації та способу їх введення в денний раціон.

Експериментальна модель МС, індукована ВККД. Одним із найбільш поширених підходів моделювання МС є застосування ВККд, яка збагачена вуглеводами (переважно сахарозою або фруктозою, інколи глюкозою) і насиченими жирними кислотами, які містяться у свинячому та яловичому жирах. Відсотковий вміст вуглеводів і жирів у цій дієті, за даними різних дослідників, суттєво коливається [41-44].

Zhou X. et al. досліджували довготривалий вплив ВККД, яка складалася з 65\% сахарози, 
25\% жирів і 10\% білків, на індукцію МС у самців щурів лінії Spraque-Dawley та вивчали біохімічні показники крові та морфологію кишківника, печінки, ПШЗ і жирової тканини [41]. Було встановлено підвищення маси тіла, ознаки ожиріння, дисліпідемію, гіперглікемію, порушення толерантності до глюкози і розвиток IP. Крім того, у цих тварин були значно підвищені рівні ліпополісахаридів, інтерлейкіну 6, фактора некрозу пухлин $\alpha$ і лужної фосфатази в гомогенатах тканини кишківника. Зі збільшенням терміну перебування щурів на дієті в тканині кишківника виявляли різний ступінь пошкодження ворсинок кишкового епітелію, зокрема ї набухання, дегенерацію та інфільтрацію запальними клітинами, а в печінці - накопичення жирових включень, запалення, фіброз і цироз. Функціональний показник, оцінки функції печінки, продемонстрував підвищення рівня аланінамінотрансферази в плазмі крові. Водночас спостерігалося збільшення діаметру острівців ПШЗ з 12 по 24 тиждень, тоді як зменшення відбувалося з 36 до 48 тижня з інфільтрацією запальними клітинами й депонуванням ліпідів у цій тканині. Гістоморфологічні дослідження виявили гіпертрофію адипоцитів та інфільтрацію жирової тканини запальними клітинами. У міру накопичення макрофагів у жировій тканині та ПШЗ збільшувався вміст фактора некрозу пухлин $\alpha$. Автори відмічали значне посилення апоптозу клітин печінки й ПШЗ.

У щурів лінії Wistar, які перебували на дієті, що містила 55\% сухого корму, 15\% яловичого жиру, 10\% сахарози, 5\% смаженого арахісу, 5\% сухого молока, 5\% яйця, 3\% кунжутної олії, $2 \%$ $\mathrm{NaCl}$ і $10 \%$ розчин сахарози, у якості питного розчину впродовж 12 тижнів виявляли суттеві біохімічні та гістологічні зміни. Вони були пов'язаніз розвитком дисліпідемії, стеатозомпечінки, зміною активності метаболічних ферментів (ліпази, гліцерин-3-фосфатдегідрогенази та глюкоза-6-фосфатдегідрогенази) і пригніченням активності рецептора $\gamma$, який активується проліфератором пероксисом у жировій тканині та печінці [42].

Показано, що приріст маси тіла піддослідних тварин залежить від хімічної структури вуглеводного компонента, його відсотку та співвідношення із жирами у складі ВККд. У дослідженнях García-Berumen C.I. et al. було проаналізовано вплив ВЖД, фруктозної дієти i їх комбінацію на моделювання МС у щурів лінї Wistar [43]. ВЖД складалася 3 47,5\% стандартного корму, 10,1\% сала, 40,6\% гідрогенізованої рослинної олії, 1,3\% холата натрію, $0,3 \%$ холіна хлориду та $0,2 \%$ тіоурацилу; фруктозна - містила 25\% фруктози в питній воді; ВККД - одночасне застосування компонентів обох дієт. Тривалість цих дієт становила 6 тижнів, після чого оцінювали масу тіла тварин, рівень глюкози, ліпідний профіль, функцію мітохондрій, рівні активних форм кисню і перекисного окислення ліпідів. Встановлено, що збільшення маси тіла спостерігалося в групах фруктозної дієти і ВЖД. Водночас суттєвих змін маси тіла щурів у групі на ВККД порівняно 3 контролем не спостерігали. Споживання кількості нормованого денного корму (20 г) у всіх досліджуваних групах не відрізнялося. Вміст тригліцеридів і холестерину зростав у всіх групах. Проте рівень першого показника був найвищим у групі фруктозної дієти, другого - у групі ВЖД.

Гістологічні дослідження печінки показали, що щури, які утримувались на 25\% розчині фруктози, мали найменш виражений стеатоз печінки (до 20\% мікровезикул і 15\% макровезикул) порівняно з усіма дослідними групами [43]. Тварини, які перебували на ВЖД, мали 40\% мікровезикул і 60\% макровезикул. Найвищий ступінь стеатозу із вогнищами запальної інфільтрації було зафіксовано в групі ВККД - 60\% мікровезикул і 80\% макровезикул (у деяких випадках гепатоцити проявляли обидві форми стеатозу) зі збільшенням на $10 \%$ кількості «роздутих» гепатоцитів порівняно з іншими двома експериментальними групами. ВККД викликала більш згубний вплив на мітохондрії, що проявлялося посиленням перекисного окислення ліпідів і продукцією активних форм кисню, зниженням активності комплексу I та інгібуванням окисного фосфорилювання. Ці результати добре узгоджуються з більш серйозним пошкодженням печінки, викликаним цією дієтою, яке проявлялося високим ступенем стеатозу і запаленням.

Порівняльний аналіз ВККД із високим вмістом жиру $(22,5 \%)$ і вуглеводів (25\% фруктози чи глюкози) продемонстрував відмінності щодо прояву метаболічних порушень у щурів Wistar [44]. Так, наприкінці 20 тижня глюкозно-жирової дієти у тварин відмічали 
збільшення маси тіла, ожиріння, зростання біомаркерів окисного стресу, підвищення рівня глюкози та інсуліну в плазмі натщесерце. Ці зміни були більш вираженими у тварин, які утримувались на глюкозно-жировій ді$€ т і$, порівняно з тваринами, які перебували на фруктозно-жировій дієті. Водночас було виявлено, що фруктозно-жирова дієта в щурів не призводила до вірогідних змін маси тіла порівняно $з$ контрольною групою, що може бути пов'язано з недостатнім відсотковим вмістом фруктози в денному раціоні щурів [44] та з прискоренням метаболічних процесів у гризунів [33].
Отже, ВККД здатна спричиняти швидший і виражений розвиток низки біохімічних і морфологічних змін, характерних для МС, на відміну від інших типів дієт.

Зведені дані щодо впливу різних типів дієт на розвиток ознак МС у гризунів представлено у таблиці.

Таким чином, можна зробити висновок, що результат моделювання МС у гризунів залежить не лише від складу і тривалості застосування дієти, але й від віку, статі, виду та лінії тварин. Тому створення моделі, яка б відповідала всім критеріям, характерним для патологічного стану людини, залишається актуальним завданням.

Таблиця. Вплив різних типів дієт на розвиток ознак МС у лабораторних тварин

Table. The impact of different types of diets on the development of MS signs in laboratory animals

\begin{tabular}{|c|c|c|c|c|c|}
\hline $\begin{array}{l}\text { Склад компонентів } \\
\text { дієти (\% від загальної } \\
\text { калорійності їжі) } \\
\text { The composition of the } \\
\text { components of the diet } \\
\text { (\% of total calories) }\end{array}$ & $\begin{array}{l}\text { Тривалість } \\
\text { дієти } \\
\text { The } \\
\text { duration of } \\
\text { the diet }\end{array}$ & $\begin{array}{l}\text { Вид і лінія } \\
\text { тварин } \\
\text { Species and line } \\
\text { of animals }\end{array}$ & $\begin{array}{l}\text { Biк i маса } \\
\text { тварин } \\
\text { Age and } \\
\text { weight of } \\
\text { animals }\end{array}$ & $\begin{array}{l}\text { Ознаки MC } \\
\text { Signs of MS }\end{array}$ & $\begin{array}{l}\text { Джерело } \\
\text { References }\end{array}$ \\
\hline \multicolumn{6}{|l|}{ Високожирова дієта } \\
\hline $\begin{array}{l}\text { Жир (30\%), холестерин } \\
\text { (1\%) }\end{array}$ & 12 тижнів & $\begin{array}{l}\text { Миші-самці лінії } \\
\text { C57BL/6J }\end{array}$ & $\begin{array}{l}4 \text { тижні } \\
-\end{array}$ & $\begin{array}{l}\text { IP, ожиріння, гіперліпідемія, стеатоз } \\
\text { печінки }\end{array}$ & $\begin{array}{l}\text { Chang TC, et al., } \\
2019[11]\end{array}$ \\
\hline Жир (45\%) & 6 місяців & $\begin{array}{l}\text { Щури-самці лінії } \\
\text { Wistar }\end{array}$ & - & $\begin{array}{l}\text { Збільшення маси тіла, IP, гіпертриглі- } \\
\text { церидемія, гіперглікемія, гіпертрофія } \\
\text { острівців ПШ3, зниження рівня експресії } \\
\text { гена глюкозного транспортера типу } 4 \\
\text { в адипоцитах }\end{array}$ & $\begin{array}{l}\text { Hafizur RM, et } \\
\text { al., } 2015[8]\end{array}$ \\
\hline Жир (20\%) & 15 тижнів & $\begin{array}{l}\text { Щури-самці лінії } \\
\text { Wistar }\end{array}$ & $\begin{array}{l}30 \text { днів, } \\
70-100 г\end{array}$ & $\begin{array}{l}\text { Збільшення маси тіла, IP, ожиріння, гіпер- } \\
\text { інсулінемія, гіперлептинемія, порушення } \\
\text { толерантності до глюкози }\end{array}$ & $\begin{array}{l}\text { Bruder- } \\
\text { Nascimento T, } \\
\text { et al., } 2013[14]\end{array}$ \\
\hline Свинячий жир (41,5\%) & 7 тижнів & $\begin{array}{l}\text { Щури-самці лінії } \\
\text { Sprague-Dawley }\end{array}$ & $\begin{array}{l}7 \text { тижнів, } \\
120-130 \text { г }\end{array}$ & Гіперліпідемія, стеатоз печінки & $\begin{array}{l}\text { Karam I, et al., } \\
2018[12]\end{array}$ \\
\hline Свинячий жир (42\%) & 12 тижнів & $\begin{array}{l}\text { Щури-самці лінії } \\
\text { Wistar }\end{array}$ & $\begin{array}{l}6 \text { тижнів } \\
-\end{array}$ & $\begin{array}{l}\text { Збільшення маси тіла, IP, зниження рівня } \\
\text { адипонектину в плазмі крові, стеатоз } \\
\text { і підвищення вмісту тригліцеридів у ткани- } \\
\text { ні печінки }\end{array}$ & $\begin{array}{l}\text { Buettner R, et } \\
\text { al., } 2006 \text { [9] }\end{array}$ \\
\hline Оливкова олія (42\%) & 12 тижнів & $\begin{array}{l}\text { Щури-самці лінії } \\
\text { Wistar }\end{array}$ & $\begin{array}{l}6 \text { тижнів } \\
-\end{array}$ & $\begin{array}{l}\text { збільшення маси тіла, IP, зниження рівня } \\
\text { адипонектину і підвищення рівня вільних } \\
\text { жирних кислот у плазмі крові, стеатоз } \\
\text { і підвищення вмісту тригліцеридів } \\
\text { у тканині печінки }\end{array}$ & $\begin{array}{l}\text { Buettner R, et } \\
\text { al., } 2006 \text { [9] }\end{array}$ \\
\hline Кокосова олія (42\%) & 12 тижнів & $\begin{array}{l}\text { Щури-самці лінії } \\
\text { Wistar }\end{array}$ & $\begin{array}{l}6 \text { тижнів } \\
-\end{array}$ & $\begin{array}{l}\text { Збільшення маси тіла, стеатоз і підвищен- } \\
\text { ня вмісту тригліцеридів у тканині печінки }\end{array}$ & $\begin{array}{l}\text { Buettner R, et } \\
\text { al., } 2006[9]\end{array}$ \\
\hline Риб'ячий жир (42\%) & 12 тижнів & $\begin{array}{l}\text { Щури-самці лінії } \\
\text { Wistar }\end{array}$ & $\begin{array}{l}6 \text { тижнів } \\
-\end{array}$ & $\begin{array}{l}\text { Зменшення маси тіла. Ознаки МС не спо- } \\
\text { стерігали }\end{array}$ & $\begin{array}{l}\text { Buettner R, et } \\
\text { al., } 2006[9]\end{array}$ \\
\hline Жир (52,5\%) & 8 тижнів & $\begin{array}{l}\text { Щури-самці лінії } \\
\text { Wistar }\end{array}$ & $\begin{array}{l}6 \text { місяців, } \\
200-220 \text { г }\end{array}$ & $\begin{array}{l}\text { Ожиріння, IP, порушення толерантності до } \\
\text { глюкози }\end{array}$ & $\begin{array}{l}\text { Клеванова ВС, } \\
\text { Тржецинський } \\
\text { СД, } 2015 \text { [5] }\end{array}$ \\
\hline Свинячий жир (58\%) & 2-4 тижні & $\begin{array}{l}\text { Щури-самці лінії } \\
\text { Wistar }\end{array}$ & $\begin{array}{l}6 \text { місяців, } \\
300-370 \text { г }\end{array}$ & $\begin{array}{l}\text { Гіперглікемія, відсутнє ожиріння, підви- } \\
\text { щення толерантності до інсуліну }\end{array}$ & $\begin{array}{l}\text { Цапенко ПК, та } \\
\text { ін., } 2020[7]\end{array}$ \\
\hline
\end{tabular}


Огляди

\begin{tabular}{|c|c|c|c|c|c|}
\hline $\begin{array}{l}\text { Склад компонентів } \\
\text { дієти (\% від загальної } \\
\text { калорійності їжі) } \\
\text { The composition of the } \\
\text { components of the diet } \\
\text { (\% of total calories) }\end{array}$ & $\begin{array}{l}\text { Тривалість } \\
\text { дієти } \\
\text { The } \\
\text { duration of } \\
\text { the diet }\end{array}$ & $\begin{array}{l}\text { Вид і лінія } \\
\text { тварин } \\
\text { Species and line } \\
\text { of animals }\end{array}$ & $\begin{array}{l}\text { Вік і маса } \\
\text { тварин } \\
\text { Age and } \\
\text { weight of } \\
\text { animals }\end{array}$ & $\begin{array}{l}\text { Ознаки MC } \\
\text { Signs of MS }\end{array}$ & $\begin{array}{l}\text { Джерело } \\
\text { References }\end{array}$ \\
\hline
\end{tabular}

\section{High fat diet}

Fat (30\%),

cholesterol (1\%)

Fat (45\%)

12 weeks

Male mice of the

C57BL/6J line

6 months

Male Wistar rats

4 weeks

-

$-$

40-50 g

Fat (20\%)

15 weeks

Male Wistar rats

30 days,

70-100 g

Lard (41.5\%)

7 weeks

Lard (42\%)

12 weeks

Male Sprague-

Dawley rats

7 weeks, 120-130 g

Male Wistar rats

6 weeks

-

Olive oil (42\%)

12 weeks

Male Wistar rats

6 weeks

-

Coconut oil (42\%)

12 weeks

Male Wistar rats

6 weeks

-

Fish oil (42\%)

12 weeks

Male Wistar rats

6 weeks

-

Fat (52.5\%)

8 weeks

Male Wistar rats

6 months, 200-220 g

Lard (58\%)

2-4 weeks

\section{Високовуглеводна дієта}

Фруктоза (10\% розчин) 2 місяці

Фруктоза (10\% розчин) 8 тижнів
Фруктоза (60\% розчин) 8 тижнів
Сахароза (30\% розчин) 8 тижнів
Фруктоза (10\% розчин) 8 тижнів
$\begin{aligned} & \text { Фруктоза (60\% у сухому } \\ & \text { кормі) }\end{aligned}$

Фруктоза (20\% розчин) 16 тижнів

Щури-самиці лінії 8 тижнів $\begin{array}{ll}\text { Щури-самці } & - \\ \text { Щури-самці } & -\end{array}$

Щури-самці - 180-220 г

Щури-самці лінії 21 день

Wistar

Щури-самці лінії Sprague-Dawley 290-350 г

Щури-самці лінії Sprague-Dawley 290-350 г

Щури-самці лінії 90 днів Wistar
IR, obesity, hyperlipidemia, hepatic steatosis Chang TC, et al., 2019 [11]

Weight gain, IR, hypertriglyceridemia, Hafizur RM, et hyperglycemia, hypertrophy of the pancretic al., 2015 [8] islets, decreased expression of the glucose transporter type 4 gene in adipocytes

Weight gain, IR, obesity, hyperinsulinemia,

hyperleptinemia, impaired glucose

tolerance

Hyperlipidemia, hepatic steatosis

Weight gain, IR, decreased adiponectin

levels in plasma, steatosis and increased triglycerides in liver tissue

Increased body weight, IR, decreased adiponectin levels and increased levels of free fatty acids in blood plasma, steatosis and increased triglycerides in liver tissue

BruderNascimento T, et al., 2013 [14]

Karam I, et al., 2018 [12]

Buettner $\mathrm{R}$, et al., 2006 [9]

Buettner $\mathrm{R}$, et al., 2006 [9]

Buettner R, et al., 2006 [9] triglycerides in liver tissue

Weight loss. Signs of MS were not observed

Buettner $\mathrm{R}$, et al., 2006 [9] Klevanova VS, Trzhetsynskyy SD., 2015 [5]

6 months, Hyperglycemia, no obesity, increased insulin Tsapenko PK, et 300-370 g tolerance al., 2020 [7]

Порушення толерантності до глюкози, IP, зниження рівня експресії глюкозного транспортера типу 4 у м'язах, гіпертригліцеридемія, стеатоз печінки без ознак запалення

збільшення маси тіла, гіперглікемія

Baena $\mathrm{M}$, et al., 2016 [21]

збільшення маси тіла, гіперглікемія, дисліпідемія

Мархонь $\mathrm{HO}$, та ін., 2015 [27] Мархонь $\mathrm{HO}$, та ін., 2015 [27]

Підвищення рівня тригліцеридів у печінці, розвиток стеатозу з ознаками помірного фіброзу

Гіпертензія, гіперурикемія, гіпертригліцеридемія

\section{Sánchez-}

Lozada LG, et al., 2007 [28]

Гіпертензія, гіперурикемія, гіпертригліцеридемія, порушення функції нирок

SánchezLozada LG, et al., 2007 [28]

Güleş Ö, Tatar M, 2020 [29] 


\begin{tabular}{|c|c|c|c|c|c|}
\hline $\begin{array}{l}\text { Склад компонентів } \\
\text { дієти (\% від загальної } \\
\text { калорійності їжі) } \\
\text { The composition of the } \\
\text { components of the diet } \\
\text { (\% of total calories) }\end{array}$ & $\begin{array}{l}\text { Тривалість } \\
\text { дієти } \\
\text { The } \\
\text { duration of } \\
\text { the diet }\end{array}$ & $\begin{array}{l}\text { Вид і лінія } \\
\text { тварин } \\
\text { Species and line } \\
\text { of animals }\end{array}$ & $\begin{array}{l}\text { Вік і маса } \\
\text { тварин } \\
\text { Age and } \\
\text { weight of } \\
\text { animals }\end{array}$ & $\begin{array}{l}\text { Ознаки MC } \\
\text { Signs of MS }\end{array}$ & $\begin{array}{l}\text { Джерело } \\
\text { References }\end{array}$ \\
\hline $\begin{array}{l}\text { Фруктоза (60\% у сухому } \\
\text { кормі) }\end{array}$ & 8 тижнів & $\begin{array}{l}\text { Щури-самці лінії } \\
\text { Wistar }\end{array}$ & 28 днів & $\begin{array}{l}\text { Порушення толерантності до глюкози, IP, } \\
\text { гіпертригліциридемія }\end{array}$ & $\begin{array}{l}\text { de Moura RF, et } \\
\text { al., } 2009[36]\end{array}$ \\
\hline $\begin{array}{l}\text { Фруктоза ( } 60 \% \text { у сухому } \\
\text { кормі) }\end{array}$ & 4 тижні & $\begin{array}{l}\text { Щури-самці лінії } \\
\text { Wistar }\end{array}$ & 90 днів & $\begin{array}{l}\text { збільшення маси тіла, порушення толе- } \\
\text { рантності до глюкози, ІР, гіперліпідемія, } \\
\text { підвищення вмісту загальних ліпідів у } \\
\text { печінці }\end{array}$ & $\begin{array}{l}\text { de Moura RF, et } \\
\text { al., } 2009[36]\end{array}$ \\
\hline Сахароза (40\% розчин) & 180 днів & $\begin{array}{l}\text { Щури-самці лінії } \\
\text { Wistar }\end{array}$ & $\begin{array}{l}60 \text { днів } \\
-\end{array}$ & $\begin{array}{l}\text { Порушення толерантності до глюкози, IP, } \\
\text { гіперліпідемія, підвищення рівнів аланін- } \\
\text { амінотрансферази, аспартатамінотрансфе- } \\
\text { рази, малонового діальдегіду і суперок- } \\
\text { сиддисмутази, зниження рівня глутатіону, } \\
\text { фіброз печінки }\end{array}$ & $\begin{array}{l}\text { Souza Cruz EM, } \\
\text { et al., } 2020 \text { [37] }\end{array}$ \\
\hline \multicolumn{6}{|l|}{ High-carb diet } \\
\hline $\begin{array}{l}\text { Fructose } \\
\text { (10\% solution) }\end{array}$ & 2 months & $\begin{array}{l}\text { Male Sprague- } \\
\text { Dawley rats }\end{array}$ & $\begin{array}{l}8 \text { тижнів } \\
-\end{array}$ & $\begin{array}{l}\text { Impaired glucose tolerance, IR, decreased } \\
\text { glucose transporter type } 4 \text { expression in } \\
\text { muscle, hypertriglyceridemia, steatosis of } \\
\text { the liver without signs of inflammation }\end{array}$ & $\begin{array}{l}\text { Baena M, et al., } \\
2016[21]\end{array}$ \\
\hline $\begin{array}{l}\text { Fructose } \\
\text { (10\% solution) }\end{array}$ & 8 weeks & Male rats & $\overline{180-220 \mathrm{~g}}$ & Weight gain, hyperglycemia & $\begin{array}{l}\text { Markhon NA et } \\
\text { al., } 2015 \text { [27] }\end{array}$ \\
\hline $\begin{array}{l}\text { Fructose } \\
\text { (60\% solution) }\end{array}$ & 8 weeks & Male rats & $\overline{180-220 ~ g}$ & Weight gain, hyperglycemia, dyslipidemia & $\begin{array}{l}\text { Markhon NA et } \\
\text { al., } 2015 \text { [27] }\end{array}$ \\
\hline Sucrose (30\% solution) & 8 weeks & Male Wistar rats & 21 days & $\begin{array}{l}\text { Elevated triglycerides in the liver, the devel- } \\
\text { opment of steatosis with signs of moderate } \\
\text { fibrosis }\end{array}$ & $\begin{array}{l}\text { Corona-Pérez A, } \\
\text { et al., } 2017 \text { [40] }\end{array}$ \\
\hline $\begin{array}{l}\text { Fructose } \\
\text { (10\% solution) }\end{array}$ & 8 weeks & $\begin{array}{l}\text { Male Sprague- } \\
\text { Dawley rats }\end{array}$ & $\overline{290-350 ~ g}$ & $\begin{array}{l}\text { Hypertension, hyperuricemia, hypertriglyc- } \\
\text { eridemia }\end{array}$ & $\begin{array}{l}\text { Sánchez- } \\
\text { Lozada LG, et } \\
\text { al., } 2007 \text { [28] }\end{array}$ \\
\hline $\begin{array}{l}\text { Fructose ( } 60 \% \text { content in } \\
\text { dry feed) }\end{array}$ & 8 weeks & $\begin{array}{l}\text { Male Sprague- } \\
\text { Dawley rats }\end{array}$ & - & $\begin{array}{l}\text { Hypertension, hyperuricemia, hypertriglyc- } \\
\text { eridemia, renal dysfunction }\end{array}$ & $\begin{array}{l}\text { Sánchez- } \\
\text { Lozada LG, et } \\
\text { al., } 2007 \text { [28] }\end{array}$ \\
\hline $\begin{array}{l}\text { Fructose } \\
\text { (20\% solution) }\end{array}$ & 16 weeks & Male Wistar rats & 90 days & Histomorphological changes of the kidneys & $\begin{array}{l}\text { Güleş Ö, Tatar } \\
\text { M, 2020 [29] }\end{array}$ \\
\hline $\begin{array}{l}\text { Fructose }(60 \% \text { content in } \\
\text { dry feed) }\end{array}$ & 8 weeks & Male Wistar rats & 28 days & $\begin{array}{l}\text { Impaired glucose tolerance, IR, hypertriglyc- } \\
\text { eridemia }\end{array}$ & $\begin{array}{l}\text { de Moura RF, et } \\
\text { al., } 2009[36]\end{array}$ \\
\hline $\begin{array}{l}\text { Fructose ( } 60 \% \text { content in } \\
\text { dry feed) }\end{array}$ & 4 weeks & Male Wistar rats & 90 days & $\begin{array}{l}\text { Weight gain, impaired glucose tolerance, IR, } \\
\text { hyperlipidemia, increased total lipids in the } \\
\text { liver }\end{array}$ & $\begin{array}{l}\text { de Moura RF, et } \\
\text { al., } 2009[36]\end{array}$ \\
\hline Sucrose (40\% solution) & 180 days & Male Wistar rats & 60 days & $\begin{array}{l}\text { Impaired glucose tolerance, IR, hyperlipi- } \\
\text { demia, elevated alanine aminotransferase, } \\
\text { aspartate aminotransferase, malonic dialde- } \\
\text { hyde and superoxide dismutase, decreased } \\
\text { glutathione, liver fibrosis }\end{array}$ & $\begin{array}{l}\text { Souza Cruz EM, } \\
\text { et al., } 2020 \text { [37] }\end{array}$ \\
\hline \multicolumn{6}{|c|}{ Висококалорійна комбінована дієта } \\
\hline $\begin{array}{l}\text { Сахароза (65\%), жири } \\
(25 \%), \text { білки (10\%) }\end{array}$ & 48 тижнів & $\begin{array}{l}\text { Щури-самці лінії } \\
\text { Sprague-Dawley }\end{array}$ & $\overline{200-250 г}$ & $\begin{array}{l}\text { Ожиріння, ІР, стеатоз печінки, дисліпідемія, } \\
\text { гіперглікемія, порушення толерантності } \\
\text { до глюкози, запалення і жирова інфільтра- } \\
\text { ція ПШ3. Підвищення рівня аланінаміно- } \\
\text { трансферази в плазмі крові та ліпополіса- } \\
\text { харидів, інтерлейкіну 6, фактора некрозу } \\
\text { пухлин а і лужної фосфатази в кишечнику }\end{array}$ & $\begin{array}{l}\text { Zhou X, et al., } \\
2014[41]\end{array}$ \\
\hline
\end{tabular}


Огляди

\begin{tabular}{|c|c|c|c|c|c|}
\hline $\begin{array}{l}\text { Склад компонентів } \\
\text { дієти (\% від загальної } \\
\text { калорійності їжі) } \\
\text { The composition of the } \\
\text { components of the diet } \\
\text { (\% of total calories) }\end{array}$ & $\begin{array}{l}\text { Тривалість } \\
\text { дієти } \\
\text { The } \\
\text { duration of } \\
\text { the diet }\end{array}$ & $\begin{array}{l}\text { Вид і лінія } \\
\text { тварин } \\
\text { Species and line } \\
\text { of animals }\end{array}$ & $\begin{array}{l}\text { Biк i маса } \\
\text { тварин } \\
\text { Age and } \\
\text { weight of } \\
\text { animals }\end{array}$ & $\begin{array}{l}\text { Ознаки MC } \\
\text { Signs of MS }\end{array}$ & $\begin{array}{l}\text { Джерело } \\
\text { References }\end{array}$ \\
\hline $\begin{array}{l}\text { Сухий корм (55\%), } \\
\text { яловичий жир (15\%), } \\
\text { сахароза (10\%), } \\
\text { смажений арахіс (5\%), } \\
\text { сухе молоко (5\%), яйця } \\
(5 \%), \text { кунжутна олія } \\
\text { (3\%), NaCl (2\%) + розчин } \\
\text { сахарози (10\%) }\end{array}$ & 12 тижнів & $\begin{array}{l}\text { Щури-самці лінії } \\
\text { Wistar }\end{array}$ & $\begin{array}{l}6 \text { тижнів, } \\
80-120 \text { г }\end{array}$ & $\begin{array}{l}\text { Дисліпідемія, стеатоз печінки, зміна актив- } \\
\text { ності метаболічних ферментів, пригнічен- } \\
\text { ня активності в жировій тканині та печінці } \\
\text { рецептора ү, який активується проліфера- } \\
\text { тором пероксисом }\end{array}$ & $\begin{array}{l}\text { Ragab SM, et } \\
\text { al., } 2015 \text { [42] }\end{array}$ \\
\hline $\begin{array}{l}\text { Стандартний корм } \\
(47,5 \%), \text { сало }(10,1 \%), \\
\text { гідрогенізована } \\
\text { рослинна олія }(40,6 \%),\end{array}$ & 6 тижнів & $\begin{array}{l}\text { Щури-самці лінії } \\
\text { Wistar }\end{array}$ & $\overline{250-350 r}$ & $\begin{array}{l}\text { Гіпертригліцеридемія, гіперхолестерине- } \\
\text { мія, стеатоз печінки з ознаками запалення, } \\
\text { посилення перекисного окислення ліпідів } \\
\text { у печінці }\end{array}$ & $\begin{array}{l}\text { García- } \\
\text { Berumen Cl, et } \\
\text { al., } 2019 \text { [43] }\end{array}$ \\
\hline
\end{tabular}

холат натрія (1,3\%),

холіна хлорид (0,3\%),

тіоурацил $(0,2 \%)+$

розчин фруктози (25\%)

Вуглеводи (42,3\%), білки 20 тижнів

(17\%), жири (22,5\%),

клітковина (3,2\%),

мінерали (5\%), вода

$(10 \%)+$ розчин фруктози

(25\%)

Вуглеводи (42,3\%), білки 20 тижнів

(17\%), жири (22,5\%),

клітковина (3,2\%),

мінерали (5\%), вода

$(10 \%)+$ питний розчин

глюкози (25\%)

\section{High-calorie combined diet}

Sucrose (65\%), fats (25\%), 48 weeks proteins (10\%)

Male SpragueDawley rats

Щури-самці ліні Wistar

Щури-самці лінії 8 тижнів, Wistar 280-310 г

8 тижнів, 280-310 г

200-250 g

Dry food (55\%), beef fat

(15\%), sucrose (10\%), roasted peanuts (5\%), milk powder (5\%), eggs (5\%), sesame oil (3\%), $\mathrm{NaCl}(2 \%)+$ sucrose solution (10\%)

Standard feed (47.5\%), lard (10.1\%), hydrogenated vegetable oil (40.6\%), sodium cholate $(1.3 \%)$, choline chloride $(0.3 \%)$, thiouracil $(0.2 \%)+$ fructose solution (25\%)

\section{2 weeks \\ 12 weeks Male Wistar rats 6 weeks,}

6 weeks

Male Wistar rats $\quad-$
Ожиріння, гіперглікемія, гіпертригліцеридемія, гіперінсулінемія, підвищення малонового діальдегіду в плазмі, збільшення рівня глутатіону в печінці
Moreno-

гіперглікемія, збільшення рівня глутатіону Fernández S, et в печінці
Moreno-

Fernández S, et al., 2018 [44] 


\begin{tabular}{|c|c|c|c|c|c|}
\hline $\begin{array}{l}\text { Склад компонентів } \\
\text { дієти (\% від загальної } \\
\text { калорійності їжі) } \\
\text { The composition of the } \\
\text { components of the diet } \\
\text { (\% of total calories) }\end{array}$ & $\begin{array}{l}\text { Тривалість } \\
\text { дієти } \\
\text { The } \\
\text { duration of } \\
\text { the diet }\end{array}$ & $\begin{array}{l}\text { Вид і лінія } \\
\text { тварин } \\
\text { Species and line } \\
\text { of animals }\end{array}$ & $\begin{array}{l}\text { Вік і маса } \\
\text { тварин } \\
\text { Age and } \\
\text { weight of } \\
\text { animals }\end{array}$ & $\begin{array}{l}\text { Ознаки MC } \\
\text { Signs of MS }\end{array}$ & $\begin{array}{l}\text { Джерело } \\
\text { References }\end{array}$ \\
\hline $\begin{array}{l}\text { Carbohydrates (42.3\%), } \\
\text { proteins (17\%), fats } \\
(22.5 \%), \text { fiber (3.2\%), } \\
\text { minerals (5\%), water } \\
(10 \%)+\text { fructose solution } \\
(25 \%)\end{array}$ & 20 weeks & Male Wistar rats & $\begin{array}{l}8 \text { weeks, } \\
280-310 \mathrm{~g}\end{array}$ & $\begin{array}{l}\text { Hypertriglyceridemia, hyperinsulinemia, hy- } \\
\text { perglycemia, increased levels of glutathione } \\
\text { in the liver }\end{array}$ & $\begin{array}{l}\text { Moreno- } \\
\text { Fernández S, et } \\
\text { al., } 2018 \text { [44] }\end{array}$ \\
\hline $\begin{array}{l}\text { Carbohydrates (42.3\%), } \\
\text { proteins (17\%), fats } \\
(22.5 \%) \text {, fiber (3.2\%), } \\
\text { minerals (5\%), water } \\
\text { (10\%) + drinking glucose } \\
\text { solution (25\%) }\end{array}$ & 20 weeks & Male Wistar rats & $\begin{array}{l}8 \text { weeks, } \\
280-310 \mathrm{~g}\end{array}$ & $\begin{array}{l}\text { Obesity, hyperglycemia, hypertriglyceri- } \\
\text { demia, hyperinsulinemia, increased plasma } \\
\text { malonic dialdehyde, increased liver glu- } \\
\text { tathione levels }\end{array}$ & $\begin{array}{l}\text { Moreno- } \\
\text { Fernández S, et } \\
\text { al., } 2018 \text { [44] }\end{array}$ \\
\hline
\end{tabular}

Примітки: «—»-дані не вказані.

Note: «—»-data not specified.

\section{Список використаної літератури}

1. González-Domínguez A, Visiedo-García FM, Domínguez-Riscart J, González-Domínguez R, Mateos RM, Lechuga-Sancho AM. Iron metabolism in obesity and metabolic syndrome. Int J Mol Sci. 2020 Aug 1;21(15):5529. doi: 10.3390/ijms21155529.

2. Grandl G, Wolfrum C. Hemostasis, endothelial stress, inflammation, and the metabolic syndrome. Semin Immunopathol. 2018 Feb;40(2):215-24. doi: 10.1007/s00281-017-0666-5.

3. Rochlani Y, Pothineni NV, Kovelamudi S, Mehta JL. Metabolic syndrome: pathophysiology, management, and modulation by natural compounds. Ther Adv Cardiovasc Dis. 2017 Aug;11(8):21525. doi: $10.1177 / 1753944717711379$.

4. Buettner R, Schölmerich J, Bollheimer LC. High-fat diets: modeling the metabolic disorders of human obesity in rodents Obesity (Silver Spring). 2007 Apr;15(4):798-808. doi: 10.1038/ oby. 2007.608 .

5. Клеванова ВС, Тржецинський СД. Антидіабетичні властивості чорноголовника родовикового за умов високожирової дієти в щурів. Фармакологія та лікарська токсикологія 2015;(4-5):59-64 (Klevanova VS, Trzhetsynskyy SD. Antidiabetic properties of blood burnet in rats under high-fat die. Farmakolohiia ta likarska toksykolohiia. 2015;(4-5):59-64. Ukrainian).

6. Онопченко ОВ, Косякова ГВ, Горідько ТМ, Бердишев АГ, Мегедь ОФ, Гула НМ. Вплив N-стеароїлетаноламіну на активність ензимів антиоксидантного захисту, вміст продуктів пол і нітрит-аніона в плазмі крові та печінці щурів 3 індукованою інсулінорезистентністю. Укр Біохім Ж. 2013 вересень-жовтень;85(5):88-96 (Onopchenko OV, Kosiakova GV, Goridko TM, Berdyschev AG, Meged OF, Hula NM. The effect of $\mathrm{N}$-stearoylethanolamine on the activity of antioxidantenzymes, content of lipid peroxidation products and nitric oxide in the blood plasma and liver of rats with induced insulin-resistance. Ukr Biokhim Zh. 2013 Sep-Oct;85(5):88-96. Ukrainian). doi: 10.15407/ubj85.05.088.

7. Цапенко ПК, Василенко МІ, Алієв РБ, Завгородній МО, Козловська МГ, Топчанюк ЛЯ, та ін. Вплив високожирової дієти на розвиток інсулінорезистентності та метаболічного синдрому у щурів. Український журнал медицини, біології та спорту. 2020;5(3):441 4 (Tsapenko PK, Vasylenko MI, Aliiev RB, Zavgorodniy MO, Kozlovska MG, Topchaniuk LYa, et al. Effects of high-fat diet on the development of insulin resistance and metabolic syndrome in rats. Ukrainskyi zhurnal medytsyny biolohii ta sportu. 2020;5(3):441-4. Ukrainian).

8. Hafizur RM, Raza SA, Chishti S, Shaukat S, Ahmed AA «Humanized» rat model of pre-diabetes by high fat diet-feeding to weaning wistar rats. Integr Obesity Diabetes. 2015;1(2):44-8. doi: 10.15761/IOD.1000111.

9. Buettner R, Parhofer KG, Woenckhaus M, Wrede CE, KunzSchughart LA, Schölmerich J, et al. Defining high-fat-diet rat models: metabolic and molecular effects of different fat types. J Mol Endocrinol. 2006 Jun;36(3):485-501. doi: 10.1677/jme.1.01909.

10. Fukumitsu S, Aida K, Ueno N, Ozawa S, Takahashi Y, Kobori M. Flaxseed lignan attenuates high-fat diet-induced fat accumulation and induces adiponectin expression in mice. $\mathrm{Br} \mathrm{J}$ Nutr. 2008 Sep;100(3):669-76. doi: 10.1017/S0007114508911570.

11. Chang TC, Chiang H, Lai YH, Huang YL, Huang HC, Liang YC, et al. Helminthostachys zeylanica alleviates hepatic steatosis and insulin resistance in diet-induced obese mice. BMC Complement Altern Med. 2019 Dec 13;19(1):368. doi: 10.1186/s12906-0192782-3.

12. Karam I, Ma N, Yang Y-J, Li J-Y. Induce hyperlipidemia in rats using high fat diet. Investigating blood lipid and histopathology. J Hematol Blood Disord. 2018 Aug;4(1):104. doi: 10.15744/24557641.4.104.

13. Udomkasemsab A, Prangthip P. High fat diet for induced dyslipidemia and cardiac pathological alterations in Wistar rats compared to Sprague Dawley rats. Clin Investig Arterioscler. 2019 Mar-Apr;31(2):56-62. doi: 10.1016/j.arteri.2018.09.004.

14. Bruder-Nascimento T, Campos DH, Alves C, Thomaz S, Cicogna AC, Cordellini S. Effects of chronic stress and high-fat diet on metabolic and nutritional parameters in Wistar rats. Arq Bras Endocrinol Metabol. 2013 Nov;57(8):642-9. doi: 10.1590/ s0004-27302013000800010.

15. Poret JM, Gaudet DA, Braymer HD, Primeaux SD. Sex differences in markers of metabolic syndrome and adipose tissue inflammation in obesity-prone, Osborne-Mendel and obesity-resistant, S5B/ $\mathrm{Pl}$ rats. Life Sci. 2021 May 15;273:119290. doi: 10.1016/j. lfs.2021.119290.

16. Surwit RS, Feinglos MN, Rodin J, Sutherland A, Petro AE, Opara EC, et al. Differential effects of fat and sucrose on the development of obesity and diabetes in $\mathrm{C} 57 \mathrm{BL} / 6 \mathrm{~J}$ and $\mathrm{A} / \mathrm{J}$ mice. Metabolism. 1995 May;44(5):645-51. doi: 10.1016/00260495(95)90123-x.

17. Prpic V, Watson PM, Frampton IC, Sabol MA, Jezek GE, Gettys TW. Adaptive changes in adipocyte gene expression differ in $\mathrm{AKR} / \mathrm{J}$ and SWR/J mice during diet-induced obesity. J Nutr. 2002 Nov;132(11):3325-32. doi: 10.1093/jn/132.11.3325.

18. Scarpace PJ, Matheny M, Moore RL, Tümer N. Impaired leptin responsiveness in aged rats. Diabetes. 2000 Mar;49(3):431-5. doi: 10.2337/diabetes.49.3.431

19. Wong SK, Chin KY, Suhaimi FH, Fairus A, Ima-Nirwana S. Animal 
Огляди

models of metabolic syndrome: a review. Nutr Metab (Lond). 2016 Oct 4;13:65. doi: 10.1186/s12986-016-0123-9.

20. Zhang DM, Jiao RQ, Kong LD. High dietary fructose: direct or indirect dangerous factors disturbing tissue and organ functions. Nutrients. 2017 Mar 29;9(4):335. doi: 10.3390/nu9040335.

21. Baena M, Sangüesa G, Dávalos A, Latasa MJ, Sala-Vila A, Sánchez RM, et al. Fructose, but not glucose, impairs insulin signaling in the three major insulin-sensitive tissues. Sci Rep. 2016 May 19;6:26149. doi: 10.1038/srep26149.

22. Rajesh R, Sreekala Venugopal. High fructose diet-induced metabolic syndrome and the functional abnormalities in the liver and kidney of Wistar albino rats. Natl J Physiol Pharm Pharmacol. 2021 Oct;11(02):156-9.

23. Tsykalo TO, Trzhetsynskyi SD. The study of hypoglycemic and hypolipidemic activity of Camelina sativa (L.) Crantz extracts in rats under conditions of high-fructose diet. Ceska Slov Farm. 2020;69(3):137-42.

24. Стецев'ят ВБ, Воронич-Семченко НМ. Інтенсивність окисної модифікації білків і пероксидації ліпідів у сироватці крові, тканинах головного мозку, печінки та підшлункової залози щурів із інсулінорезистентністю та вродженим йододефіцитом. Прикарпатський вісник НТШ. Пульс. 2019;(6):11520 (Stetsevyat VB, Voronych-Semchenko NM. The intensity of oxidative modification of proteins and peroxidation of lipids in the blood serum, brain, liver and pancreas tissues of rats with insulin resistance and congenital iodine deficiency. Prykarpatskyi visnyk NTSh. Puls. 2019;(6):115-20. Ukrainian). doi: 10.21802/23047437-2019-6(58)-115-120.

25. Catena C, Giacchetti G, Novello M, Colussi G, Cavarape A, Sechi LA. Cellular mechanisms of insulin resistance in rats with fructose-induced hypertension. Am J Hypertens. 2003 Nov;16(11 Pt 1):973-8. doi: 10.1016/s0895-7061(03)01002-1.

26. Do MH, Lee E, Oh MJ, Kim Y, Park HY. High-glucose or -fructose diet cause changes of the gut microbiota and metabolic disorders in mice without body weight change. Nutrients. 2018 Jun 13;10(6):761. doi: 10.3390/nu10060761.

27. Мархонь НО, Мамчур ВЙ, Жилюк ВІ, Лєвих АЕ. Порівняльний аналіз експериментальних підходів у відтворенні метаболічного синдрому. Вісник проблем біології і медицини. 2015;1(117):156-62 (Markhon NA, Mamchur VI, Zhylyuk VI, Lievykh AE. Comparative analysis of experimental approaches in reproducing of metabolic syndrome. Visnyk problem biolohii i medytsyny. 2015;1(117):156-62. Ukrainian).

28. Sánchez-Lozada LG, Tapia E, Jiménez A, Bautista P, Cristóbal M, Nepomuceno T, et al. Fructose-induced metabolic syndrome is associated with glomerular hypertension and renal microvascular damage in rats. Am J Physiol Renal Physiol. 2007 Jan;292(1): F423-9. doi: 10.1152/ajprenal.00124.2006.

29. Güleş Ö, Tatar M. Effects of fructose-induced metabolic syndrome on kidney histology in rats. Kocatepe Vet J. 2020;13(2):203-9.

30. Miranda CA, Schönholzer TE, Klöppel E, Sinzato YK, Volpato GT, Damasceno DC, et al. Repercussions of low fructose-drinking water in male rats. An Acad Bras Cienc. 2019 Feb 14;91(1): e20170705. doi: 10.1590/0001-3765201920170705.

31. Bocarsly ME, Powell ES, Avena NM, Hoebel BG. High-fructose corn syrup causes characteristics of obesity in rats: increased body weight, body fat and triglyceride levels. Pharmacol Biochem Behav. 2010 Nov;97(1):101-6. doi: 10.1016/j.pbb.2010.02.012.

32. Sandeva RV, Mihaylova SM, Sandeva GN, Trifonova KY, PopovaKatsarova RD. Effect of high-fructose solution on body weight, body fat, blood glucose and triglyceride levels in rats. J Biomed Clin Res. 2015;8(1):5-8. doi: 10.1515/jbcr-2015-0143.

33. Tillman EJ, Morgan DA, Rahmouni K, Swoap SJ. Three months of high-fructose feeding fails to induce excessive weight gain or leptin resistance in mice. PLoS One. 2014 Sep 11;9(9): e107206. doi: 10.1371/journal.pone.0107206.

34. Dupas J, Feray A, Goanvec C, Guernec A, Samson N, Bougaran P, et al. Metabolic syndrome and hypertension resulting from fructose enriched diet in Wistar rats. Biomed Res Int. 2017;2017:2494067. doi: $10.1155 / 2017 / 2494067$.

35. Шупрович АА, Гуріна НМ, Корпачева-Зінич ОВ. Порушення обміну сечової кислоти у щурів з експериментальним інсулінорезистентним синдромом, індукованим фруктозою. Фізіол. журн. 2011;57(1):72-81 (Shuprovich AA, Gurina NM,
Korpacheva-Zinych OV. Disordes of uric acid metabolism in rats with fructose induced experimental insulin resistance syndrome. Fiziol Zhurn. 2011;57(1):72-81. Ukrainian).

36. de Moura RF, Ribeiro C, de Oliveira JA, Stevanato E, de Mello MA. Metabolic syndrome signs in Wistar rats submitted to different high-fructose ingestion protocols. Br J Nutr. 2009 Apr;101(8):117884. doi: 10.1017/S0007114508066774.

37. Souza Cruz EM, Bitencourt de Morais JM, Dalto da Rosa CV, da Silva Simões M, Comar JF, de Almeida Chuffa LG, et al. Long-term sucrose solution consumption causes metabolic alterations and affects hepatic oxidative stress in Wistar rats. Biol Open. 2020 Feb 28;9(3): bio047282. doi: 10.1242/bio.047282.

38. Oliveira DT, Fernandes IDC, Sousa GG, Santos TAPD, Paiva NCN, Carneiro CM, et al. High-sugar diet leads to obesity and metabolic diseases in ad libitum -fed rats irrespective of caloric intake. Arch Endocrinol Metab. 2020 Feb;64(1):71-81. doi: 10.20945/23593997000000199.

39. Oron-Herman M, Kamari Y, Grossman E, Yeger G, Peleg E, Shabtay Z, et al. Metabolic syndrome: comparison of the two commonly used animal models. Am J Hypertens. 2008 Sep;21(9):1018-22. doi: 10.1038/ajh.2008.218.

40. Corona-Pérez A, Díaz-Muñoz M, Cuevas-Romero E, LunaMoreno D, Valente-Godínez H, Vázquez-Martínez $\mathrm{O}$, et al. Interactive effects of chronic stress and a high-sucrose diet on nonalcoholic fatty liver in young adult male rats. Stress. 2017 Nov;20(6):608-17. doi: 10.1080/10253890.2017.1381840.

41. Zhou X, Han D, Xu R, Li S, Wu H, Qu C, et al. A model of metabolic syndrome and related diseases with intestinal endotoxemia in rats fed a high fat and high sucrose diet. PLoS One. 2014 Dec 11;9(12): e115148. doi: 10.1371/journal.pone.0115148.

42. Ragab SM, Abd Elghaffar SKh, El-Metwally TH, Badr G, Mahmoud MH, Omar HM. Effect of a high fat, high sucrose diet on the promotion of non-alcoholic fatty liver disease in male rats: the ameliorative role of three natural compounds. Lipids Health Dis. 2015 Jul 31;14:83. doi: 10.1186/s12944-015-0087-1.

43. García-Berumen CI, Ortiz-Avila O, Vargas-Vargas MA, Del Rosario-Tamayo BA, Guajardo-López C, Saavedra-Molina A, et al. The severity of rat liver injury by fructose and high fat depends on the degree of respiratory dysfunction and oxidative stress induced in mitochondria. Lipids Health Dis. 2019 Mar 30;18(1):78. doi: 10.1186/s12944-019-1024-5.

44. Moreno-Fernández S, Garcés-Rimón M, Vera G, Astier J, Landrier JF, Miguel M. High fat/high glucose diet induces metabolic syndrome in an experimental rat model. Nutrients. 2018 Oct 14;10(10):1502. doi: 10.3390/nu10101502.

\section{Experimental modeling of diet-induced metabolic syndrome in laboratory animals}

\section{N.I. Levchuk, O.S. Lukashenia, O.I. Kovzun}

SI «V.P. Komisarenko Institute of Endocrinology and Metabolism of the National Academy of Medical Sciences of Ukraine»

Abstract. Understanding the causes of occurrence, diagnosis, prevention and treatment of metabolic syndrome (MS) remains a priority of modern endocrinology. This is a symptom complex characterized by the main clinical manifestations such as an increase in body weight, impaired glucose tolerance, dyslipidemia, arterial hypertension and insulin resistance (IR). It is currently one of the most complex and dangerous diseases, preceding the onset of type 2 diabetes and the development of cardiovascular complications, which are the main causes of mortality in the population. Considering the rapid increase in morbidity in recent years in all countries, it became necessary for experiments on animals to gain new knowledges about the mechanisms of the pathological process development 
and its some manifestations, the use of drug compounds for their safe use and correction of this condition. Rats and mice are most often preferred for experimental modeling of MS among laboratory animals. This literature review is devoted to a comparative analysis and brief description of experimental modeling of diet-induced MS in rodents. The main types of diets (high-fat, high-carbohydrate, high-calorie combined) are discussed the drug compounds and the differences in the manifestation of pathological state under various nutritional conditions in animals, depending on their species, line, sex, age, conditions and experiment duration are also highlighted in the article. It was shown that the severity of biochemical and pathomorphological changes characteristic of metabolic disorders depends on the type and percentage of diet components. The reproduction of modeling conditions and the heterogeneity of MS manifestation in animals creates certain difficulties in substantiating the obtained scientific results in accordance with the stated purpose of the study. It is these circumstances that attract increased scientific and practical interest on the part of researchers.

Keywords: metabolic syndrome, insulin resistance, diet.

\section{Экспериментальное моделирование метаболического синдрома, индуцированного диетой, у лабораторных животных}

\section{Н.И. Левчук, О.С. Лукашеня, Е.И. Ковзун}

ГУ «Институт эндокринологии и обмена веществ им. В.П. Комиссаренко НАМН Украины»

Резюме. Понимание причин возникновения, диагностики, профилактики и лечения метаболического синдрома (МС) остается приоритетным направлением современной эндокринологии. Этот симптомокомплекс характеризуется основными клиническими проявлениями - увеличением массы тела, нарушением толерантности к глюкозе, дислипидемией, артериальной гипертензией и инсулинорезистентностью (ИР). В настоящее время является одним из самых сложных и наиболее опасных заболеваний, предшествующих возникновению сахарного диабета 2-го типа и развитию сердечно-сосудистых осложнений, которые являются основными причинами смертности населения. Учитывая стремительный рост заболеваемости во всех странах мира на протяжении последних лет, возникает потребность в проведении экспериментов на животных с целью получения новых знаний о механизмах развития патологического процесса и отдельных её проявлений, использования лекарственных соединений для их безопасного применения и коррекции данного состояния. Для экспериментального моделирования МС чаще всего отдают предпочтение исследованиям на крысах или мышах. Данный обзор литературы посвящен сравнительному анализу и краткому описанию экспериментального моделирования МС, индуцированного диетой, у грызунов. Рассмотрены основные типы диет (высокожировая, высокоуглеводная, высокока- лорийная комбинированная) и освещены различия проявления патологического состояния при различных условиях питания у животных в зависимости от их вида, линии, пола, возраста, условий и продолжительности эксперимента. Было показано, что степень выраженности развития биохимических и патоморфологических изменений, характерных для метаболических нарушений, зависит от типа и процентного содержания компонентов диеты. Воспроизведение условий моделирования и неоднородность проявления МС у животных создает определенные трудности при обосновании полученных научных результатов в соответствии с поставленной целью исследования. Именно эти обстоятельства привлекают повышенный научно-практический интерес со стороны исследователей.

Ключевые слова: метаболический синдром, инсулинорезистентность, диета.

Для цитування: Левчук НI, Лукашеня ОС, Ковзун ОІ. Експериментальне моделювання метаболічного синдрому, індукованого дієтою, у лабораторних тварин. Ендокринологія. 2021;(3):298-310. DOI: DOI: 10.31793/1680-1466.2021.26-3.298.

Адреса для листування: Левчук Наталія Іванівна, levnataly@ meta.ua; ДУ «Інститут ендокринології та обміну речовин ім. В.П. Комісаренка НАМН України», вул. Вишгородська, 69, Київ 04114, Україна.

Відомості про авторів: Левчук Наталія Іванівна, канд. біол. наук, старш. наук. співроб., старший науковий співробітник відділу фундаментальних і прикладних проблем ендокринології, ORCID: 0000-0003-0482-5176; Лукашеня Оксана Сергіївна, канд. біол. наук, старший науковий співробітник відділу фундаментальних і прикладних проблем ендокринології, ORCID: 0000-00030088-4099; Ковзун Олена Ігорівна, д-р біол. наук, проф., заступник директора Інституту з наукової роботи, ORCID: 0000-0001-81647671.

Особистий внесок: Н.І. Левчук - аналіз літературних джерел і написання тексту; О.С. Лукашеня - написання таблиці, переклад резюме, підготовка статті до друку; О.І. Ковзун - розробка концепції статті та консультація під час її редагування.

Фінансування: стаття підготовлена в рамках бюджетного фінансування НАМН України.

Декларація з етики: автори задекларували відсутність конфлікту інтересів і фінансових зобов'язань.

Стаття: надійшла до редакції 07.09.2021 р.; перероблена 24.09.2021 р.; прийнята до друку 01.10.2021 р.; надрукована 20.10.2021 p.

For citation: Levchuk NI, Lukashenia OS, Kovzun OI. Experimental modeling of diet-induced metabolic syndrome in laboratory animals. Endocrynologia. 2021;(3):298-310. DOI: DOI: 10.31793/16801466.2021.26-3.298.

Correspondence address: Levchuk Nataliia Ivanivna, levnataly@ meta.ua; SI «V.P. Komisarenko Institute of Endocrinology and Metabolism of the National Academy of Medical Sciences of Ukraine», Vyshgorodska Str., 69, Kyiv 04114, Ukraine.

Information about the authors: Levchuk Nataliia Ivanivna, Cand. Sci. (Biology), Senior Scientist, Senior Research Fellow of the Department of Fundamental and Applied Problems of Endocrinology, 


\section{Огляди}

ORCID: 0000-0003-0482-5176; Lukashenia Oksana Serhiivna, Cand. Sci. (Biology), Senior Research Fellow of the Department of Fundamental and Applied Problems of Endocrinology, ORCID: 00000003-0088-4099; Kovzun Olena Igorivna, Dr. Sci. (Biology), Prof., Deputy Director of the Institute for Scientific Affairs, ORCID: 00000001-8164-7671.

Personal contribution: N.I. Levchuk — analysis of literary sources and text writing; O.S. Lukashenia - table creation, translation of a resume, preparation of article for publishing; O.I. Kovzun formulation of the article concept, advising on the editing.

Funding: The article was prepared within the framework of budgetary funding of the National Academy of Medical Sciences of Ukraine.

Declaration of ethics: The authors have declared no conflicts of interest or financial obligations.

Article: received 07 September 2021; revised 24 September 2021; accepted 01 October 2021; published 20 October 2021.

Для цитирования: Левчук НИ, Лукашеня ОС, Ковзун ЕІ. Экспериментальное моделирование метаболического синдрома, индуцированного диетой, у лабораторных животных Эндокринология. 2021;(3):298-310. DOI: DOI: 10.31793/16801466.2021.26-3.298.
Адрес для переписки: Левчук Наталия Ивановна, levnataly@ meta.ua; ГУ «Институт эндокринологии и обмена веществ им. В.П. Комиссаренко НАМН Украины», ул. Вышгородская, 69, Киев, 04114, Украина.

Сведения об авторах: Левчук Наталия Ивановна, канд. биол. наук, старш. науч. сотр., старший научный сотрудник отдела фундаментальных и прикладных проблем эндокринологии, ORCID: 0000-0003-0482-5176; Лукашеня Оксана Сергеевна, канд. биол. наук, старший научный сотрудник отдела фундаментальных и прикладных проблем эндокринологии, ORCID: 0000-0003-0088-4099; Ковзун Елена Игоревна, д-р биол. наук, проф., заместитель директора Института по научным вопросам, ORCID: 0000-0001-8164-7671.

Личный вклад: Н.И. Левчук - анализ литературных источников и написание текста; О.С. Лукашеня - написание таблицы, перевод резюме, подготовка статьи к печати; Е.И. Ковзун — разработка концепции статьи и консультация во время её редактирования.

Финансирование: статья подготовлена в рамках бюджетного финансирования НАМН Украины.

Декларация по этике: авторы задекларировали отсутствие конфликта интересов и финансовых обязательств.

Статья: поступила в редакцию 07.09.2021 г;; переделана 24.09.2021 г.; принята к печати 01.10.2021 г.; напечатана 20.10.2021 г. 